\title{
Afro-Brazilian Religions and "Aggiornamento": The Magna Carta of Umbanda
}

\author{
Artur Cesar Isaia \\ La Salle University - UNILASALLE, Canoas \\ RS/ Federal University of Santa Catarina - UFSC \\ CNPq 1C Researcher
}

\begin{abstract}
This text deals with the perspective of an Afro-Brazilian religion, Umbanda, on current issues, representing an attempt to update its discourse, with some of its leaders as spokespeople. This perspective is clarified in a document, the Magna Carta of Umbanda, which seeks to associate religion with current guidelines aimed at micro and macro social organization in the country and worldwide. In this regard, the document adopts a position in face of issues involving citizenship, gender, ecology and reproductive policy, among others.
\end{abstract}

Keywords: Human Rights; Umbanda; Mediumistic Religions.

\section{Introduction}

Umbanda is a mediumistic ${ }^{2}$ and Afro-Brazilian religion, extremely polysemic if we think about the reality of the Brazilian religious realm. It worships spirits considered the constituents of Brazilian socio-historical reality, such as the first landowners, the Indians; black Africans, who were brought to Brazil in the slavery period, in addition to a wide range of spirits like children, exus, pomba gira (the latter referring to both feminine and masculine transgression). Through the mediumistic trance, these spirits begin to appear in the intimacy of men and women who attend the Umbanda temples, called "terreiros" in Brazil. Umbanda arose in the first half of the 20th century and it had not developed a more explicit position on issues such as human rights, bioethics and ecology. Hence the interest in the document that I focus on here: the Magna Carta of Umbanda. This document was made public in 2013, signed by significant elements of religion in Brazil. Since then, it has been a topic of discussion in and outside the religious realm. The document clarifies the position of Umbanda concerning complex and current issues, able to divide not only members of the religious realm, but public opinion.

The document addresses issues that range from the preservation of the environment to racial and gender prejudice, and from contraceptive policy to euthanasia, as well as animal rights. In addition, problems which focus mainly on living a pluralistic democracy are central aspects in the Magna Carta, such as the limits of state action on individuals and participation in national politics at all levels.

Given the importance of the topics, whose position the Umbanda representatives try to clarify in this document, I believe that the study and dissemination of this document deserve special attention from all researchers who investigate religions in Brazil and their relationship with political struggles and the affirmation of human rights. On the other hand, the document is evidence of a position not only intra-religious but also clearly focused on current macro politics. The document is part of a scenario in which religions are constantly challenged by the perplexities of men and women who experience a moment characterized by the "acceleration of time" (Koselleck, 2006), in which millennial certainties become existential controversies and questions.

\section{Umbanda leaders and the struggle for representativeness}

The Magna Carta of Umbanda was a group of Umbanda leaders' initiative, led by Ortiz Belo de Souza, an Umbanda priest from São Paulo, city where he was born in 1969 and where he develops his religious activity at Umbanda Gateways Temple. The religious men who signed this document developed, like all Umbanda priests, a personal investment in launching as leaders of the religion. That is because unlike other religions, in which there is a sacred book that founds and structures its doctrinal universe, as well as institutionalized authorities that speak for them, Umbanda has neither one thing nor the other. At Umbanda, temples are more subject to the authority of the leader, who is entrusted with leadership that involves ritual, behavioral, and, of course, doctrinal issues.

\footnotetext{
${ }^{1}$ The term is used as an analogy to the Catholic phenomenon of the attempt to update itself with the modern world, and was especially introduced in and after the Second Vatican Council (author's note).

${ }^{2}$ The expression refers to the reality of mediums, intermediaries between spirits and men, present in the French Spiritism of the $19^{\text {th }}$ century and extremely familiar with Brazilians' vocabulary and daily life (author's note).
} 
Thus, for those who endeavor to study Umbanda and other Afro-Brazilian religions, generalizations are not welcome (Prandi, 2005) and it is necessary to know the daily life of the different terreiros, where we will find the true "application" of the religion. Despite this atomization of authority in Umbanda, historically we find some leaders and intellectuals linked to the religion, carrying out an effort, both representative and of unifying forces. The first three Umbanda Congresses point in this direction, in Rio de Janeiro in 1941, 1961 and 1973. These Congresses were moments when the project of some leaders was established, trying to speak for Umbanda and to represent it in the religious and civil context. Historically, Umbanda has not developed a strictly monopolizing sacerdotal layer of the management of the sacred, a process described by Bourdieu (2001) as inherent to the deepening of the division of religious work. However, the emergence of Umbanda leaders and intellectuals imbued "with a normative project, which wants to establish itself in the multifaceted practices that characterized and characterize this religion", is undeniable (Isaia, 2012, p. 1). Ortiz Belo de Souza is one of those leaders. In the absence of a consensus on who exercises authority and what the responsibilities of Umbanda leaders are, internal disputes are very common. Regarding the Magna Carta itself, different groups, represented by different leaderships, tried to have the last word about the document, provoking discussions within the Umbanda area. Marme Rosa, an Umbanda leader, born in Santa Maria, RS, who currently performs religious activities in Balneário Camboriú, SC, reports the division of forces that occurred when the text of the Magna Carta of Umbanda was launched in São Paulo in 2013 (Rosa, 2016). On this occasion, another Umbanda leadership of the state of São Paulo, supported by some federations of São Paulo ABC region ${ }^{3}$, tried to revert back Ortiz Belo de Souza's authority in conducting and representing the document. Marme Rosa himself ratifies the unifying project, able to reach an interlocution based on a representative authority and on a political and doctrinal explanation, inherent in the document proposed by Ortiz Belo de Souza:... There are many people who will support to register or in the Ministry of Culture (the text of the Magna Carta of Umbanda). We will register it. This is Umbanda. (...) Moreover, it has already been approved and recognized by the whole country (Rosa, 2016).

\section{The Magna Carta: Umbanda leaders and the perplexities of a changing world}

The Magna Carta of Umbanda integrates a broader project defended by Ortiz Belo de Souza, in order to clarify a position for religion and to enable an effective dialogue with civil society and government authorities. Thus, Father Ortiz, as he is known among the Umbandists, founded the Political Umbanda Movement (MPU). This movement emerged in 2012 aiming to enable discussion and political organization among Umbandists. The movement emerged integrating the strategy of organizing the Umbandists politically and bringing to the parliament candidates in tune with "Priests of Umbanda and Candomblét" (Movimento, 2016). On behalf of the movement, Ortiz Belo de Souza presented Ronei Costa Martins as a candidate tuned in to Umbanda, in the elections for State Deputy in São Paulo in 2014 (Movimento, 2016). Not having been elected a state deputy, Ronei Costa Martins is currently a town councilor in Limeira, SP, having already held the position of President of the Municipal Chamber of this city, from 2013 to 2014 , integrating the Workers' Party (Câmara, 2017).

The Umbandists' attempt to organize themselves around political leaders who represented their interests in state parliaments was not new. Brown (1985) presented the political participation of Umbandists in the 1950s and 1960s as a "group of political interest", gathered around leaderships. Birman (1985) defended the role of political mediation of the Umbanda Federations. Concone and Negrão (1985) had already studied some processes of political patronage in Umbanda in the state of São Paulo in the 1970s. In Rio Grande do Sul, Isaia (2009), Horta (2016), and Moraes (2017) analyzed the political trajectory of Moab Caldas as an articulator of Umbanda interests and their first representative in the state parliament in the late 1950s and 1960s.

As one would expect in a document proposed by an Afro-Brazilian religion, the Magna Carta has a special interest in prejudices, highlighting the issue of the so-called "racial prejudice": Umbanda does not accept ethnic and racial prejudice. Racial prejudice is, above all, a demonstration of spiritual ignorance and ignorance of the Divine Laws. He who belittles or persecutes his brother due to the color of his skin or to any other ethnic characteristic, violates the golden rule present in the most different spiritual and religious traditions (Carta, 2012).

It could not be different, as Umbanda, since the second half of the $20^{\text {th }}$ century, has been reconfiguring its identity towards the African past, surpassing a rebellious representation to it, characteristic of the early times of religion (ISAIA, 2010).

\footnotetext{
${ }^{3}$ The term ABC Region refers to an industrial region located in São Paulo, Brazil. In this region are the cities of Santo André, São Caetano e São Bernardo.

${ }^{4}$ Candomble is an Afro-Brazilian religion, in which not the spirits (as it happens in the Umbanda) but the gods of the African pantheon, the Orixás, are invoked (Author's note). 
The Magna Carta of Umbanda articulates with the ethnic, identity and religious strengthening of appreciation of the Afro-descendant past, typical of the first decades of the $21^{\text {st }}$ century (Silva, 2011).

In order to explain the position of Umbanda on subjects close to the political representation of religion, human rights, environmental policy, among others, emerges the idea of a Magna Carta from the MPU discussions. The connection of this movement with the UN Universal Declaration of Human Rights is highlighted by Ortiz Belo de Souza in the presentation of the document: A religion that values equality, respecting the Universal Declaration of Human Rights through the United Nations Letter, this major document should have the mission to dignify its thousands of followers, leaving the legacy to posterity (Souza, 2017).

The proposal was to formalize the document at an Umbanda National Congress, held in São Paulo City Hall, in August 2013. It was in this Congress that there was a division of forces between MPU and leaders of the ABC Region, reported by Rosa (2016), previously emphasized. This division seems to have been the reason why MPU presented the Magna Carta of Umbanda as an initiative of the group led by Ortiz Belo da Souza, without the participation of aforementioned leaderships, as written in the current version of the document (Souza, 2017).

The interesting point in the proposal of the Magna Carta is that the document is not presented as Umbanda codification. Unlike previous initiatives, whose normative claim was explicit, the document is introduced as an unfinished project. The submission document, by Ortiz Belo de Souza, proposes reviewing, completing, rethinking the Magna Carta according to the demands of society and the transformations of religion. On the other hand, unlike other documents, especially those produced in the middle of the last century, interested in standardizing religion liturgical and doctrinally (Isaia, 2012), the Magna Carta has been introduced only as "a guiding base for answers to students of theology, sociology, philosophy and followers of religion" (Documento, 2012). Likewise, a mark of difference of the document, compared to others previously published by Umbanda leaders and intellectuals, is associated with the foreign aspiration of umbanda practice. While recognizing that Umbanda is a Brazilian religion, the document clarifies its introduction to a world of increasingly less rigid boundaries:It is important to emphasize that Umbanda is in several countries, bringing peace and rise of a religion that defends equal rights, respecting the plurality of each nation. The bases of the Magna Carta of Umbanda are the record of the principles followed by Umbanda religious men throughout the world (Carta, 2012).

\section{Inclusion, Family and the Right to Life in the Magna Carta of Umbanda}

Another difference of the Magna Carta, compared with other documents registered by Umbanda representatives concerns its inclusive character in the recognition of same-sex marriages, gender diversity and, consequently, plurality of family models. In this sense, the document explicitly states that in Umbanda: Every human being is seen as a spiritual sibling, and any sexual orientation and gender identity is accepted. Thus, religion understands and welcomes Spirits, not gender or sexuality. Our Spirit Guides do not teach discrimination or prejudice, since Umbanda welcomes everyone. Therefore, it is crucial to respect each individual's condition: heterosexuality, homosexuality, bisexuality, transsexuality and intersexuality are intimate and personal matters (Carta, 2012).

Thus, the document recognizes religious marriage as a sacrament, though it also provides divorced people with the possibility of marriage and, consequently, the formation of a new family. In the document, marriage is seen as the basis of family organization, and the spouses' heterosexuality, homosexuality, bisexuality, transsexuality and intersexuality is irrelevant. "We reserve equal rights of marriage to everyone, respecting the sexual orientation of each person" (Carta, 2012). Likewise, regarding the issue of adoption, the Magna Carta prescribes equal rights between "heterosexual, homosexual, bisexual, transsexual and intersexual parents" (CARTA, 2012). The relationship between the so-called social minorities appears in Babalorixá Magno Constantino's testimony about the Magna Carta of Umbanda. The aforementioned priest traces identity marks for Umbanda as a religion essentially close to these minorities, which would require a clear position of religion in relation to them: African religions and we, Umbandists, are the ones who suffer the most, we are marginalized all the time by Christian religions (more specifically evangelical ones), since our worship is composed of worshipers of those minorities: Black, Indigenous and African people, Lesbians, Gays, Bisexuals, Transvestites, Transsexuals, Transgenders, single mothers, low income people among other groups. We do embrace the minorities, because we are not proselytizers, we are all Divine and sacred (Souza, 2017, p. 47).

Magno Constantino's perspective extremely indicates the transformations presented in the speeches of Umbanda intellectuals and leaders nowadays. At a time when Brazilian society presents significant transformations towards the identities that until recently had no socio-political visibility, this Umbanda priest manifests an inclusive project for Umbanda religion. With this position, on the other hand, Constantino draws a differential line concerning the denominations that do not recognize, do not support or do not clarify a position on these issues. 
Likewise, the Magna Carta of Umbanda wanted to clarify the position of religion on issues that focused on the religious foundations of life. Therefore, it presents its perspective on abortion, euthanasia and death penalty. In view of all these issues, the position of the Magna Carta of Umbanda is against them, since they are seen as an attack against the right to life, because "only the creator, through His Omniscience, Omnipresence, and Omnipotence, knows the moment of the carnal death of every individual" (Carta, 2012). With regard to the right to life of the unborn, the document considers it inviolable from the moment of conception. On the other hand, birth control is encouraged as a matter of personal decisions, including the choice of contraceptive methods, seen as "a way of protecting life" (Carta, 2012). Still regarding contraceptives, it clearly mentions the use of condoms. They are not considered mere contraceptives, but ways to avoid sexually transmitted diseases (STDs). Therefore, the document clearly adopts a position aimed at a positive understanding of sexual pleasure, not subordinated to procreation, as it considered in the West since the classical period with Aristotle (Zilles, 2009). In line with Aristotelian biology, Christian theologians condemned acts considered contrary to nature (not practiced for the purpose of procreation) and accepted those considered according to nature (practiced for the purpose of procreation) (Zilles, 2009). In this sense, the document states that: Umbanda supports the use of condoms and contraceptive methods, as means of preventing STDs (sexually transmitted diseases) and prevention of unwanted pregnancy. Everyone must know and choose the moment to conceive a baby, who will need love, understanding, education, guidance and discernment throughout its life. In this sense, the use of contraceptive methods is a means of protecting life (Carta, 2012).

The Carta Magna of Umbanda seems to meet the characteristics pointed out by Natividade and Oliveira (2007) to the Afro-Brazilian religious field, in the sense of a greater flexibility of sexual morality. The explicit reference in the document in relation to the acceptance of new family models, as well as of homosexual, transsexual, bisexual and intersexual behavior, goes in this direction. Specifically about the topic of the homosexual presence in Afro-Brazilian religions, there is already considerable literature since the pioneering work of Ruth Landes (1967). Therefore, having studied the rules, principles and prohibitions in the Afro-Brazilian field, Monique Augras argues that more than a closed system of enunciations, we must meet the daily modulations of Orixás' will: "That is to say, what matters is not the blind obedience to the principles, but the fundamental thing is to meet the gods' will" (Augras, 2011, p. 175). This behavioral flexibility that is part of the Magna Carta of Umbanda would be unthinkable in a document such as the Annals of the First Brazilian Congress of Spiritism of Umbanda (Federação, 1941), completely resistant to the African past and totally focused on meeting the symbolic codes and objectives current in the first half of the 20th century (Isaia, 2009). In addition to these positions, the document considers the laicism of the state as the fundamental principle for meeting the demands of a plural society.

\section{Human Rights and Ecology in the Magna Carta of Umbanda}

In the Magna Carta, we find another important issue, related to human rights and the rules of social coexistence, when referring to the ecological characteristic of Umbanda. In this sense, in its Introduction, the document shows Umbanda as a "Christian, natural and ecological" religion (Carta, 2012). Not only does it see the defense of the environment as a priority, given that the land is everyone's common home, but it also explains the close connection that there must be between the worship of Orixás, to Ancestors and to nature:By explaining that Umbanda as a Christian, Natural and Ecological religion has among its followers nature advocates, we understand that the sacred Orixás magnetically manifest with more intensity in the vibratory sites of nature, where the religious followers of Umbanda constantly go and promote concentrations for energy restoration, harmonization and capture of sublime energies, rebalancing them with the forces of Mother Nature (Carta, 2012).

By reading the document, we can clearly understand its relation with the holistic and global perspective led by the United Nations (Ianni, 2001; Henderson, 2003) in terms of thinking about a world community governed, among other criteria, by the demands of harmony between men and the environment. This is a project closely linked to that of a religious reformulation, with the end of the particularism of belief.

In addition, when discussing about the link between the defense of the environment and the characteristics intrinsic to Umbanda, with the prescription of "practices" in the woods, waterfalls, seas, rivers, among other natural resources, the document also prescribes the need to use biodegradable materials. UMBANDA defends Nature, cares for woods, seas, rivers, waterfalls and springs. It also cares for the fauna and flora, thus contributing to the International Treaties for the preservation of Nature, indicating the need for modes of development that do not harm it (Carta, 2012).

Therefore, the document not only deepens its defense of the ecology, but also permeates into an extremely current issue, relating human rights policy and the right to the environment. This link is another common aspect between the Magna Carta of Umbanda and documents issued by the UN, such as the Stockholm Declaration of 1972 (Declaration, 2018). 
In this document, the defense of life on a healthy planet is specified as a fundamental human right, subject to concrete actions by the member states, in articulation with Agenda 21, signed in Rio de Janeiro in 1992 (Conferência, 1995).

Therefore, the Magna Carta of Umbanda embeds much more in a current agenda, when it presents its position on sustainability issues and their relation with human rights. Moreover, human rights and the right to enjoy a balanced environment are interconnected, since both have a common objective, which is the quality of life of all inhabitants on earth (Hammartrön \& Cenci, 2012).

\section{Conclusion}

The Magna Carta of Umbanda, seen as a historical source, brings some explicit or indicative pieces of information, which are extremely important to historians. Analyzing its "monumental" character it is possible to find peculiarities which are absent in other documents registered by Umbanda leaders in the past. For example, its target audience and the topics listed as priorities in the position of those who have the project to speak on behalf of the Brazilian Umbanda. Unlike other documents, the Magna Carta is designed to a larger audience than the followers of Umbanda religion, also aiming at non-religious audiences and, aiming primarily at students and intellectuals linked to Human Sciences. They even appear in the document preceding the supporters of Umbanda, as a target audience to be aimed at. Likewise, the document tries to clarify the Umbanda position on extremely current issues and that are often subject to doctrinal discussions in the current religious organizations. On the other hand, the explicit position on issues such as gender identities, contraception, abortion and new family models are signs of an attempt by Umbanda leaders to respond to extremely current issues. Of course, due to the characteristics of Umbanda, the position of the document on such heated and controversial discussions cannot be regarded as definitive. The empirical multiplicity and the atomization of the exercise of authority revealed by Umbanda in Brazil completely betray the possibility of thinking of the document as a canonical reality. However, the treatment and centrality given to the issue of human rights in the Magna Carta emphasize the propositional project of the group that wrote it trying to create an updated Umbanda at discourse level and in tune with the plurality and complexity of the contemporary world.

\section{References}

Conferência das Nações Unidas sobre Meio Ambiente e o Desenvolvimento (1995). Agenda 21. Brasília: Câmara dos Deputados.

Augras, M. (2011). Quizilas e Preceitos. Transgressões, reparação e organização dinâmica do mundo. In: MOURA, Carlos Eugênio Marcondes de. Culto aos Orixás. Voduns e Ancestrais nas Religiões Afro-Brasileiras. Rio de Janeiro: Pallas..

Bourdieu, P.(2001). A economia das trocas simbólicas. São Paulo: Perspectiva.

Birman, P. (1985). Registrado em Cartório, com firma reconhecida: a mediação política das federações da umbanda. In: Brown, Diana et al. Umbanda e Política. Rio de Janeiro: Marco Zero.

Brown, D. (1985). Uma História da Umbanda no Rio. In: Brown, Diana et al. Umbanda e Política. Rio de Janeiro: Marco Zero.

Câmara Municipal de Limeira. Galeria de Vereadores. Retrieved from: http://limeira.sp.leg.br/historia/galeriaVereadores.php?leg=59.

Carta Magna da Umbanda. (2012). (Personal Archive Marne Franco Rosa). No typographical notes.

Carta Magna da Umbanda. (2013). Retrieved from: https://www.google.com.br/search?q=carta+magna+da+umbanda\&source=lnms\&tbm=isch\&sa=X\&ved=0ahU KEwjEycDOsJ3cAhWLr1kKHUd0Bp8Q_AUICigB\&biw=1920\&bih=974\#imgrc=GR9ulHIWKAsslM: .

Declaration of the United Nations Conference onde Human Environment. (1972). Retrieved from: https://mwvlw.rlp.de/fileadmin/mwkel/Abteilung_2/8206/06_Nachhaltigkeit_global/1972_Stockholm_Erklaer ung_en.pdf.

Documento Oficial para a Religião de Umbanda. Carta Magna Internacional da Umbanda. (2012). (Personal Archive Marne Barcelos). No typographical notes.

Concone, M. H.; Negrão, L.N. (1985). Umbanda: da repressão à cooptação. In: Brown, Diana et al. Umbanda e Política. Rio de Janeiro: Marco Zero, 1985.

Hammarstön, F.; Cenci, D.R. (2012). Direitos Humanos e meio ambiente: a educação ambiental como forma de fortalecer a interrelação. Revista Eletrônica em Gestão, Educação e Tecnologia Ambiental REGET/UFSM. $5(5)$.

Henderson, H. (2003). Além da Globalização. Modelando uma economia sustentável. São Paulo: Editora PensamentoCultrix. 
Horta, J.S.. Do terreiro à tribuna: a atuação de Moab Caldas na Assembleia Legislativa do Rio Grande do Sul (19591969) (2016). Trabalho de Conclusão de Curso (Licenciatura em História). Universidade Federal do Rio Grande do Sul, Porto Alegre.

Ianni, O. (2001). Teorias da Globalização. Rio de Janeiro: Civilização Brasileira.

Isaia, A.C. (2012). Umbanda, intelectuais e nacionalismo no Brasil. Fênix. Revista de História e Estudos Culturais, $9(3)$.

(2010). Intolerância e preconceito na obra dos intelectuais da Umbanda. In: MANOEL, Ivan Aparecido; ANDRADE, Solange Ramos de. Tolerância e intolerância nas manifestações religiosas. Franca: UNESP.

(2009). O outro lado da repressão: a Umbanda em tempos de Estado Novo. In: Crenças, sacralidades e religiosidades. Entre o consentido e o marginal. Florianópolis: Insular.

Koselleck, R. (2006). O futuro passado. Contribuição à semântica dos tempos históricos. Rio de Janeiro: Editora PUCRio.

Landes, R. (1967). A cidade das mulheres. Rio de Janeiro: Civilização Brasileira.

Moraes, G. S.. Moab Caldas: discursos que rompem silêncios na tribuna (1958-1966) (2017). Dissertação (Mestrado em História) Programa de Pós-Graduação em História, Universidade Federal de Santa Maria, Santa Maria.

Movimento Político Umbandista. (2016). Retrieved from: http://movimentopoliticoumbandista.blogspot.com.br/.

Natividade, M.; Oliveira, L. (2007). Religião e intolerância à homossexualidade. Tendências contemporâneas no Brasil. In: SILVA, Wagner Gonçalves da. Intolerância Religiosa. Impactos do neopentecostalismo no campo religioso afro-brasileiro. São Paulo: Editora da USP.

Prandi, R. (2005). Segredos guardados. Orixás na alma brasileira. São Paulo: Companhia das Letras.

Rosa, M.F. (2016). Entrevista. Balneário Camboriú, 30, mai, 2016. (Author's Archive). No thypographical notes.

Silva, W.G. (2011). Religião e identidade cultural negra: católicos, afrobrasileiros e neopentecostais. Cadernos de Campo. 8(20).

Souza, O.B. de et al (2017). Carta Magna da Umbanda. Retrieved from: http://movimentopoliticoumbandista.blogspot.com.br.

Zilles, Urbano (2009). Visão cristã da sexualidade humana. Teocomunicação. 39(3). 